\title{
Correction to: Ambitious subsidy reform by the WTO presents opportunities for ocean health restoration
}

\author{
Christopher Costello ${ }^{1,2}\left({ }^{10} \cdot\right.$ Katherine Millage $^{1} \cdot$ Sabrina Eisenbarth $^{3} \cdot$ Elsa Galarza ${ }^{4} \cdot$ Gakushi Ishimura $^{5}$. \\ Laura Lea Rubino $^{6} \cdot$ Vienna Saccomanno $^{1} \cdot$ U. Rashid Sumaila ${ }^{7,8} \cdot$ Kent Strauss $^{2}$
}

Published online: 28 December 2020

(C) The Author(s) 2020

\section{Correction to: Sustainability Science https://doi.org/10.1007/s11625-020-00865-z}

The article Ambitious subsidy reform by the WTO presents opportunities for ocean health restoration, written by Christopher Costello, Katherine Millage, Sabrina Eisenbarth, Elsa Galarza, Gakushi Ishimura, Laura Lea Rubino, Vienna Saccomanno, U. Rashid Sumaila and Kent Strauss, was originally published electronically on the publisher's internet portal on 28 September 2020 without open access. With the author(s)' decision to opt for Open Choice the copyright of the article changed on 08 December 2020 to $($ ) The Author(s) 2020 and the article is forthwith distributed under a Creative Commons Attribution 4.0 International License (https://creativecommons.org/licenses/by/4.0/), which permits use, sharing, adaptation, distribution and reproduction in any medium or format, as long as you give appropriate credit to the original author(s) and the source, provide a link to the Creative Commons license, and indicate if changes were made.

The original article has been updated.

Open Access This article is licensed under a Creative Commons Attribution 4.0 International License, which permits use, sharing, adaptation, distribution and reproduction in any medium or format, as long as you give appropriate credit to the original author(s) and the source, provide a link to the Creative Commons licence, and indicate if changes were made. The images or other third party material in this article are included in the article's Creative Commons licence, unless indicated otherwise in a credit line to the material. If material is not included in the article's Creative Commons licence and your intended use is not permitted by statutory regulation or exceeds the permitted use, you will need to obtain permission directly from the copyright holder. To view a copy of this licence, visit http://creativecommons.org/licenses/by/4.0/.

Publisher's Note Springer Nature remains neutral with regard to jurisdictional claims in published maps and institutional affiliations.

The original article can be found online at https://doi.org/10.1007/ s11625-020-00865-z.

$\triangle$ Christopher Costello

costello@bren.ucsb.edu

1 Bren School of Environmental Science and Management, University of California, Santa Barbara, Santa Barbara, CA, USA

2 Department of Economics, University of California, Santa Barbara, Santa Barbara, CA, USA

3 Land, Environment, Economics and Policy Institute, University of Exeter Business School, Exeter, UK

4 Research Center, Universidad del Pacífico, Lima, Peru

5 Faculty of Agriculture, Iwate University, Morioka, Japan

6 Environmental Defense Fund, New York, NY, USA

7 Institute for the Ocean and Fisheries, The University of British Columbia, Vancouver, BC, Canada

8 School of Public Policy and Global Affairs, The University of British Columbia, Vancouver, BC, Canada 